\title{
ポリ塩化ビニリデンフィルムの酸素透過性におよぼす 加熱処理の影響
}

茂木幸夫

(1978 年 8 月 18 日受理)

\author{
Influence of Heating on the Oxygen Gas Permeability \\ of Polyvinylidene Chloride Film
}

\section{Sachio MotegI*}

\begin{abstract}
Studies have been done to investigate how the heating conditions affect the change of the oxygen gas permeability of polyvinylidene chloride (PVDC) film.

PVDC film was placed in contact with several kinds of food-simulating substances, such as fish meat paste, olive oil, lard, distilled water, and $n$-heptane, and heated under various conditions.

A lowering in the oxygen gas permeability and new absorptions at $1700-1760 \mathrm{~cm}^{-1}$ and $1050-1300 \mathrm{~cm}^{-1}$ in the infrared spectrum of PVDC film were observed after the film was put in contact with some food-simulating substance on one side and heated. It was found that the lowering of the oxygen gas permeability of the PVDC film was caused by the migration of an additive in the film into the food-simulating substance.

It was noted that the degree of the migration was high in PVDC film containing large amounts of additive. A high degree of migration was noted also in the case of high temperature heating.

The oxygen gas permeability of the PVDC film which was put in contact with fish meat paste and heated at $120^{\circ} \mathrm{C}$ for 20 minutes was higher than that of an unheated film. Nevertheless, the additive residual in the film decreased. It seems that some ingredients in the food had penetrated into the film during the heating at high temperature and acted as a plasticizer.
\end{abstract}

高分子フィルムの気体透過性に和よぼす要因について は数多くの報告があり, 総説としてもまとめられてい る゙。しかしポリ塩化ビニリデン (PVDC) フィルムの 気体透過性に和上ぼす加熱処理の影響についての報告は 見当らない。そこで今回，PVDCフィルムにいくつか の食品類似物を接触させ，加熱した場合の酸素透過保数 の变化を追求した。

\section{実 䲗方法}

包蔆材 $3 \sim 8 \%$ の多塭基性脂肪酸誘導体を添加剂之 する透明のロール状の PVDCフィルムを特に製造し供 試した。

\section{食品類似物 次のものを使用した。}

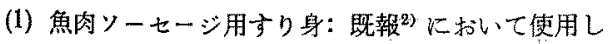
たものと同一組成のもの。

(2) オリーブ油: 局方。びれ入り。

(3) ラード：油䥒薬品 (株)製。びん入り。
（4）水: 蒸留水。

(5) nーヘプタン: 試薬特級。

装置次のものを使用した。

(1) 䔟行試験用装置: ポリオレフィン等衛生協議会制 定の片面溶出試験に用いる金属製の溶出試験用装置。32

(2) 加圧加熱殺菌器: 細菌培地減菌用才一トクレー $>^{*}$

(3) 酸素透過率测定器: Modern Controls Inc. 社製 Oxygen permeability tester, Mocon OX-Tran 100 型。

（4）赤外分光光度計：日本分光工業(秼)製，回折格子 赤外分光光度計，IRA-2 型。

実験操作 (1) 移行試験用試料の調製：魚肉ソーセー ジ用すり身を使用する場合には，2 通りの方法で行なつ た。第1の方法は，通常の魚肉ソーセージを製造する方 法と同じである。交ず包装材を折幅 $8 \mathrm{~cm}$, 長さ $30 \mathrm{~cm}$ のチューブに加エし，一端とアルミニウムワイヤーで結

\footnotetext{
* 姐ダ夕株式会社製品安全部 (Asahi-Dow Ltd., 1-1-2, Yuraku-cho, Chiyoda-ku, Tokyo, Japan).
} 
さつし，内容物が漏洩しないことを確認した。ついでこ れにすり身を約 $400 \mathrm{~g}$ 充てん，結己つ密封し，加生加就 狆菌器を用いて $120^{\circ} \mathrm{C} て ゙ 20$ 分間加熱した。第 2 の方 法注, 直径が $11.3 \mathrm{~cm}$ 以上の円形となるように切断し た包装材を移行試験用装置に七ットする力法である。こ の場合は200g の原料ずり身を包装材の片面に接触させ 密閉し，以下，第 1 の力法と同槏に加熱処理を行なつ 心。その他の食品類似物を使用する場合法，魚肉ッ一七 一シすり身を使用する場合に用いな第 2 の方法に準拠し た。ただし， $n$ ーヘブタンを使用する場合の加等は恒温水 槽を用い, $90^{\circ} \mathrm{C}, 75^{\circ} \mathrm{C}, 60^{\circ} \mathrm{C}$ のいずれかの温度で 30 分間とした。

（2）包装材からの総溶出量の測定：食品類似物として 水ならびに $n$-ヘプタンを使用する場合は, 既報の方法4) にしたがって，蒸発残留物の形て総溶出量を算出した。

(3）包装材中の添加剤の定量: 既報の方法りにしたが つて実施した。

（4）食品類似物中の添加剂の定量：既報の方法4にに たがつて実施した。

(5) 包装材の酸素透過率の湘定：等王法りにしたがつ て測定した。すなわち，加熱前の包装材はそのます, 加 熱後の包装材は，亲ず表面をエチルエーテルをしみ这ま せた脱脂綿にて軽く拭い、食品類似物を除去した後、流水 にて軽く洗い，水分を沪紙にて吸い取り畭燥してから供 試した。まず包装材を直径が $11 \mathrm{~cm}$ 以上の円形切切断
し，酸素透過率測定器にセットした。ついで，一定温度に 抬ける酸素透過量 $Q$ を溂定し，この $Q$ 之包装材の厚从 より酸素透過保数を算定し， cc(STP) $\mathrm{cm} / \mathrm{cm}^{2} \cdot \mathrm{s} \cdot \mathrm{cmHg}$ の単位で表示した。

（6）包装材の赤外略収スペクトルの測定：酸素透過索 の測定に供した包装材の一部を使用し, 赤外分光光度計 により透過光による吸収を測定した。

\section{実験結果ならひに考察}

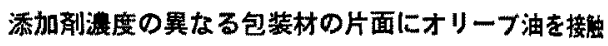
させ加熱した場合の酸素透過保数の変化 Fig. 1 下注 添加剂濃度が 3，5，6， または $8 \%$ で，厚さ $40 \mu \mathrm{m}$ の PVDC フィルムの片面炕オリーブ油を接触させ，60年 あるいは $90^{\circ} \mathrm{C} て ゙ 30$ 分間加熱した後の酸素透過保数P ならびに添加剤线存率を示す。いずれの包装材儿批いて

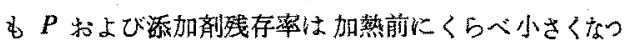
ている。むた両者間には相関がみられる。これは加熱て 上り包装材中の添加戍が減少したために，Pが小さくな

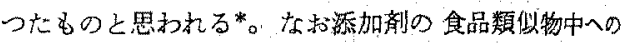
移行は加熱温度が高いはど，また添加剤濃度の高い包姿 林はど、その程度は大きかつた。

片面を全品類似物と接蜰させ加整した包装材における 酸素透過係数の変化 Table 1 には片面だけを食品類倾 物に接触させた包装材の加熱前後の厚さ，P, 添加剂䂝 存率省示吉。

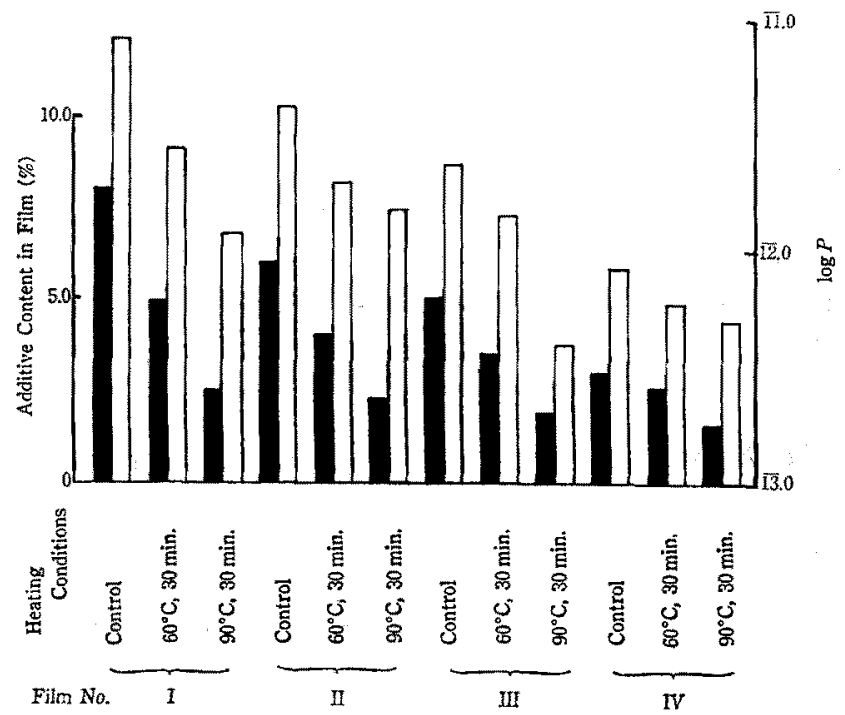

Fig. 1. Changes in oxygen gas permeability $\left(P: \mathrm{cc} \cdot \mathrm{cm}^{2} / \mathrm{cm} \cdot \mathrm{sec} \cdot \cdot \mathrm{cmHg}\right.$ at $\left.30^{\circ} \mathrm{C}\right)$ and additive contents in PVDC film which had been contacted with olive oil on one side and heated under various conditions.

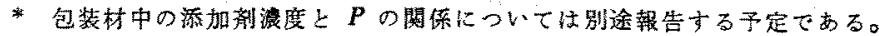


Table 1. Changes in properties of PVDC film after having contacted with various food simulating substances on one side and heated under various conditions

\begin{tabular}{|c|c|c|c|c|c|c|c|c|}
\hline \multirow{2}{*}{$\begin{array}{l}\text { Exp. } \\
\text { No. }\end{array}$} & \multirow{2}{*}{$\begin{array}{c}\text { Food } \\
\text { simulating } \\
\text { substances }\end{array}$} & \multicolumn{2}{|c|}{ Heating condition } & \multicolumn{3}{|c|}{ Properties of film } & \multirow{2}{*}{$\begin{array}{l}\text { Total } \\
\text { amounts of } \\
\text { migrant } \\
\text { from film } \\
\left(\mathrm{mg} / \mathrm{cm}^{2}\right)\end{array}$} & \multirow{2}{*}{$\begin{array}{c}\text { Additive } \\
\text { Residual } \\
\text { in film } \\
(\%)\end{array}$} \\
\hline & & $\begin{array}{c}\text { Temp. } \\
\left({ }^{\circ} \mathrm{C}\right)\end{array}$ & $\underset{(\min )}{\text { Time }}$ & $\begin{array}{l}\text { Thickness } \\
(\mu \mathrm{m})\end{array}$ & $Q^{* 1}$ & $p^{* 2}$ & & \\
\hline \multirow[t]{8}{*}{$I$} & Control I & & & 43 & 72 & 4.71 & - & 100 \\
\hline & Fish meat paste & 120 & 20 & 44 & 63 & 4.12 & - & 91.8 \\
\hline & $n$-heptane & 60 & 30 & 45 & 42 & 2.88 & 250 & 59.3 \\
\hline & & 75 & 30 & 44 & 33 & 2.21 & 165 & 33.9 \\
\hline & & 90 & 30 & 45 & 24 & 1.64 & 50 & 0 \\
\hline & Olive oil & 120 & 20 & 45 & 16 & 1.09 & - & 58.2 \\
\hline & Lard & 120 & 20 & 45 & 16 & 1.10 & 一 & 10.5 \\
\hline & Distilled water & 120 & 20 & 50 & 61 & 4.66 & 11 & 96.1 \\
\hline \multirow[t]{6}{*}{ II } & Control II & & & 40 & 41 & 2.4 & - & 100 \\
\hline & Fish meat paste & 120 & 20 & 40 & 36 & 2.2 & - & 94.1 \\
\hline & $n$-heptane & 60 & 30 & 40 & 25 & 1.5 & 180 & 55.6 \\
\hline & & 75 & 30 & 40 & 18 & 1.1 & 120 & 32.3 \\
\hline & & 90 & 30 & 40 & 13 & 0.8 & 80 & 0 \\
\hline & Olive oil & 120 & 20 & 41 & 9 & 0.6 & - & 61.6 \\
\hline
\end{tabular}

*1 Oxygen gas transmission rate; $\mathrm{cc} / \mathrm{cm}^{2} 24 \mathrm{~h}$, atm at $30^{\circ} \mathrm{C}$.

*2 Oxygen gas permeability; $\times 10^{-12} \mathrm{cc} \cdot \mathrm{cm} / \mathrm{cm}^{2} \cdot \mathrm{sec} \cdot \cdot \mathrm{cmHg}$ at $30^{\circ} \mathrm{C}$.

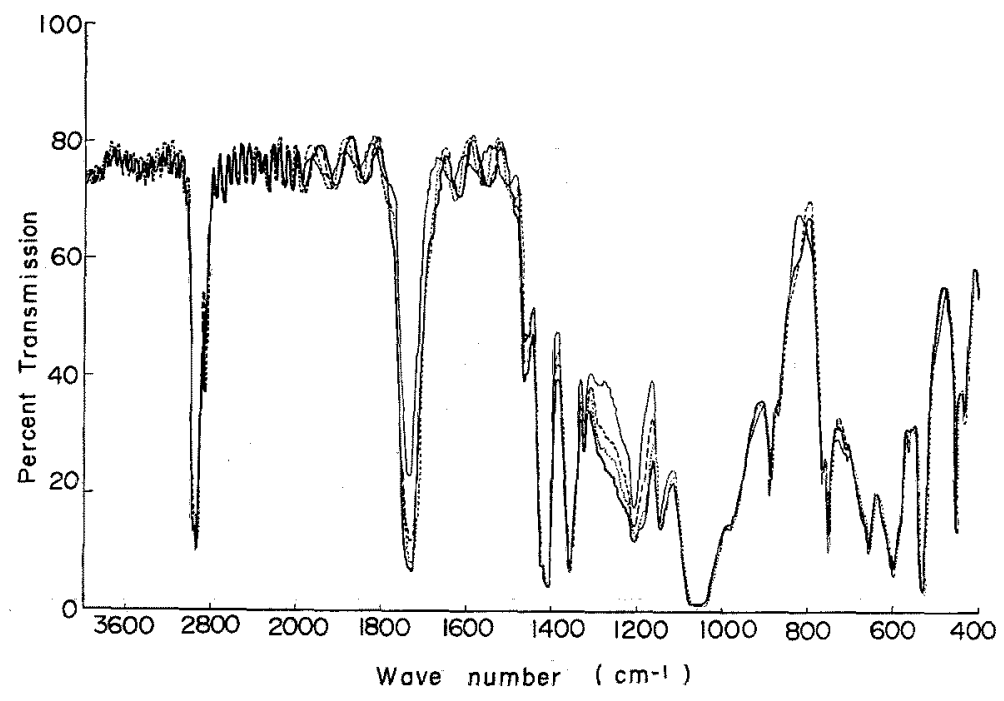

Fig. 2. Change in the infrared spectra of PVDC film which had been contacted with $n$ heptane on one side and heated under various conditions.

$\left(\square:\right.$ control (unheated) $\quad: 60^{\circ} \mathrm{C}$ for $30 \mathrm{~min} . \cdots-5^{\circ} \mathrm{C}$ for $30 \mathrm{~min}$ )

nーヘブタンを使用した場合には，加熱温度が高くな るにしたがつて PVDC フィルムのP P は小くなつて いる。同時に 添加剂残存率もとれに 比例して減少し, PVDC ブィルム中の添加剂が $n$-ヘプタン中に移行した ことが判る。この関保を赤外吸收スペクトルで示すと
Fig. 2 の上らになり，多塞基性脂肪酸誘導体の特長を 示寸波数 $1700 \sim 1760 \mathrm{~cm}^{1}$ および $1050 \sim 1300 \mathrm{~cm}^{-1}$ の

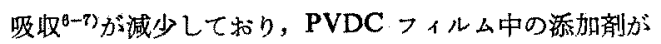
減少していることが判明した。

オリーブ油怙よびラードを使用した場合の包荠材の挙 


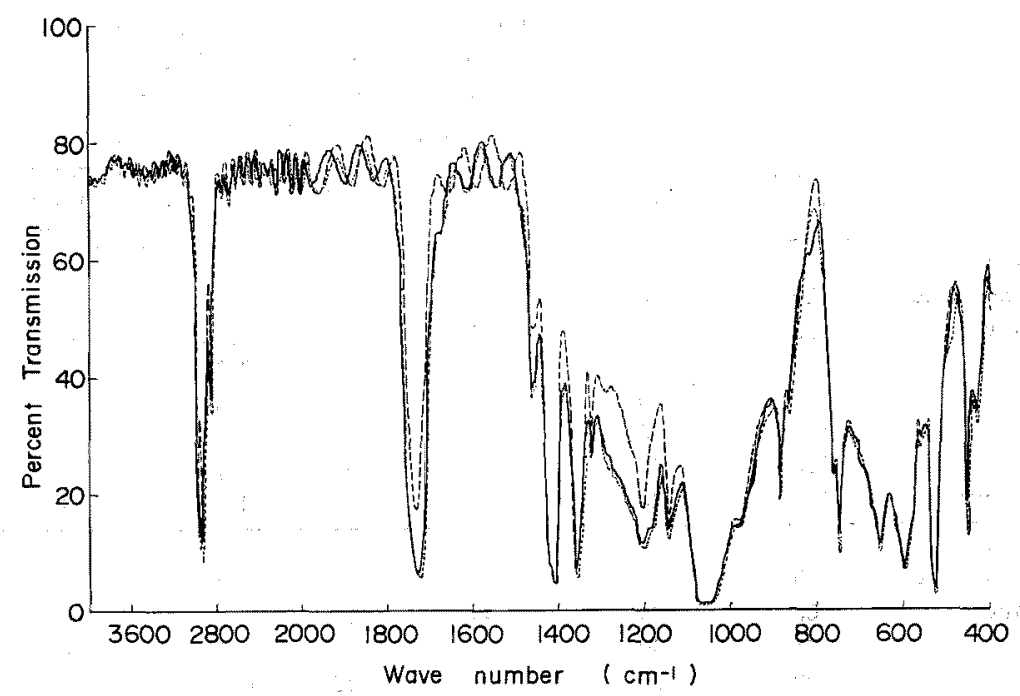

Fig. 3. Change in the infrared spectra of PVDC film which had been contacted with olive oil or distilled water on one side and heated at $120^{\circ} \mathrm{C}$ for 20 minutes.

(-: control, ......... : distilled water, ....-.: olive oil)

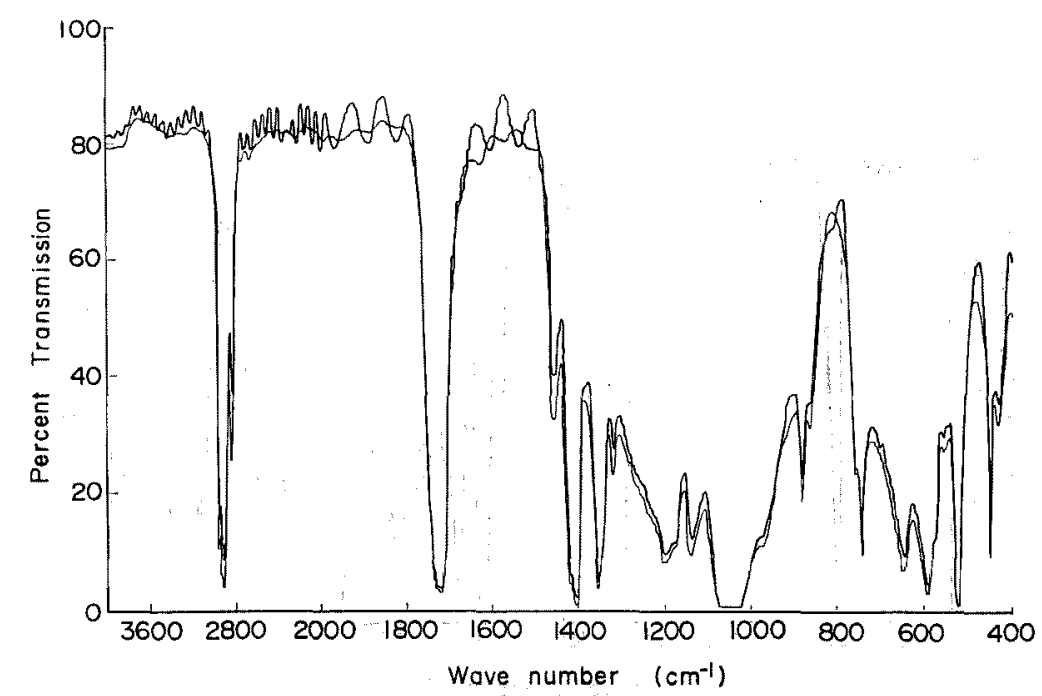

Fig. 4. Change in the infrared spectra of PVDC film used for packaging fish sausage which had been heated at $120^{\circ} \mathrm{C}$ for 20 minutes.

(-: control (unheated), $\longrightarrow$ : heated),

動はまつたく同じであつた。すなわち，加熱後のPVDC フィルムの $P$ は小さくなつており，また添加剂残存率 は 60\% 前後であつた。Fig. 3 に示す赤外吸収スペクト ルからも明らかなよらに, 派加剤の存在を示す吸収が減 少して枋り，添加剂が減少していることが判明した。 水を使用した場合には，加熱後の PVDCフィルム中

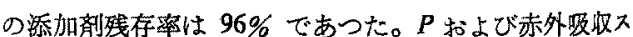
ペクトル (Fig. 3) は加熱前とほとんど変化がなかかた。 この場合には包装材からの添加剂の溶出はなからたるの と考える。

すり身を使用した場合には，加熱後の PVDCフィル ムの P は小さくなつていたし，添加剤牫存率む隇少し 
ていることが判明した。

通常の方法て拥製した魚肉ソーセージの包装材におけ 万敢素透過俰数の查化 加熱前の包装材のPは $5.77 \times$ 10-12 であつたのに対し加熱後のそれは $9.38 \times 10^{-12}$ に 增加した。また厚み性加熱前が $43 \mu \mathrm{m}$ であったのに対 し，加熱後には $48.7 \mu \mathrm{m}$ となり膨潤しているように見 受けられた。赤外吸収スペクトルは Fig. 4 に示すよう に加熱前後においてほとんど変化がなかった。しか し，この魚肉ンーセージの包装材中の残存添加剂浱度は 83.5\%であつた，これ迄の実験結果にもとづけば，添加 戍量が少なくなれば・は小さくなる筈である。それにる かかわらずアが大きくなつたといらことは, 包装材中の 添加剂肪食品中に梨行する反面, PFAB ${ }^{8)}$, OstROMOW' FiGGE ${ }^{10)}$ が指摘しているように魚肉ンーセージ中の水 分中油脂分などの特定成分が加熱加工中に PVDC フィ

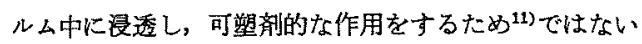
かと考える。この魚肉ソーヒージでは包装材は片面が原 料すり身江接し，他の面は水蒸気化接する状態で加熱さ れた。したがつて包菨材中の添加物の移動の系上しては 水蒸気中への揮発と食品中への溶出の 2 つが考えられ る。その結果, 包装材の外々内との王力差の関係で， ま 才゙包装材中の添加剤が移動し, その後に, 食品中の特定 成分が包装材中に浸透するのではないかと考える。これ に対し, 移行試験用装置を使用して加熱した場合は, 包 装材の片面は原料すり身に接しているが，他の面は装置 に接しているので添加剂は食品中に溶出するだけで，食 品中の特定成分の包装材中への浸透怯おこらないものと 考える。な打使用した添加剤の赤外吸収スペクトルの吸 彼は，油脂のそれ之類似しているので，両者の識别は困 難であつた。

\section{約}

(1) PVDC フィルムに, 食品類似物として, 魚肉》 一セー济用すり身，オリーブ油，ラード，水または $n$ ヘブタンを接触させ, 高温で加熱した場合の酸素透過係 数の変化を追求した。

（2）食品類似物を片面だけに接触させ加熱した場合， PVDC フィルムの酸素透過伱数恃小さくなつた。また
赤外四収スペクトルに执いては，特定波数に打故る四収 が減少した。これは包装材中の㬄加剤が食品類似物中に 移行したことに起因するものと判断した。

(3) 添加刘の食品類似物中への移行の程度は, 加热湿 度が高い汪ど，また添加剤濃度の高い包装材ほど大きか つた。

（4）通常の製造方法にもとずきすす身を充てんし， 加压加熱した魚肉ンーセージの包装材で酸素透過保数 が增加した。この場合, 包装材中の添加剂浱度は減少し ていた。

（5）上記の現象俚，魚肉ンーセージ中の特定成分が包 装材中に浸透し，可塑剤的な作用をするためであるらと 推察した。

本研究遂行に祭し有益なる御助言をいただいた工盖技 術院製品科学研究所基礎珄能部包装材料科神谷義紀主任 研究官ならびに内藤泰俊主任研究官に感謝いたします。

\section{文献}

1) 岸本 昭：高分子七水分 (高分子学会編)，第 1 版, 幸書房, 東京, 1972, pp. 83-98.

2）茂木幸夫：日水誌 44，1047-1051 (1978)。

3）ポリオレフィン等衛生㙝議会編：オレフィンおよ びスチレン系合成樹脂製食品容器包装等に関する 自主規制基準, 第 1 版, 東京, 1974, pp. 108115.

4）茂木幸夫・上田和男 - 田中溥美 -大田 实 - 山木 清史：日水誌, 44, 789-796 (1978)，

5) 仲川 勤：高分子と水分 (高分子学会螎), 第 1 版, 幸青房, 東京, 1972, pp. 288-317。

6) W. Merse und H. Ostromow: Kunststoffe 54, 213-216 (1964).

7) 小椋二郎・川和田七郎：壏化ビニールとポリマー $9(2), 18-26$ (1969) .

8) W. PFAB: Deut. Lebensm.-Rundschau. 68, 350-354 (1972).

9) H. Ostromow und A. CanjI: Deut. Lebensm,Rundshau. 69, 189-192 (1973).

10) K. FIGGE: Food Cosmetic Toxcol. 11, 964974 (1973).

11) W.B. KUnz and R.T.K. CoRnwell: Tappi 45, 583-588 (1962). 